\title{
STAMPS ON DEBENTURES.
}

To the Editor of the Journal of the Institute of Actuaries.

SrR,-As many students are doubtless constantly referring to Mr. Barrand's valuable paper on Debentures in the 34th volume of the Journal, it may not be out of place to call attention to the decision of the Court of Appeal, on the 6th instant, as to the stamping of debentures.

Mr. Barrand referred in his paper (J.I.A., xxxiv, 431) to the case of Rowell \& Son, Limited $v$. The Commissioners of Inland Revenue (L. R. 1897, 2 Q. B. 194), in which it was decided that a debenture containing an obligation on the issuer to redeem at a premium should be stamped, not merely on its par value, but also on the premium; and he further mentioned that the decision applied only to debentures redeemable at a premium in any event, and not to those merely containing an option to redeem at a premium. In the discussion on the paper, I pointed out that the case of The Knight's Deep Limited $v$. The Commissioners of Inland Revenue (L R. 1899, 1 Q. B. 345, 79 L.T. Rep. 704), decided the week previous to the reading of the paper, was in conflict with the latter statement. The debentures in that case were redeemable at par by annual drawings commencing in 1902, but they bore a condition enabling the issuing company to redeem them, at any time after July 1900, at a premium, on giving six months' notice and under certain other conditions. The Divisional Court held that, notwithstanding the fact that the premium was not payable in any event, the duty should be assessed on the par value plus the premium, and on the 30 March last, the Inland Revenue authorities issued a circular calling attention to the decision.

The Company, however, appealed, and the Appeal Court have now unanimously allowed the appeal, holding that the duty should be charged on the par value of the debentures only (Times, 7 December 1899).

Unless, therefore, the decision of the Court of Appeal should be reversed by the House of Lords, it would appear that if a debenture is only redeemable at a premium under certain conditions at the option of the issuing company, and is redeemable at par if the company do not exercise such option, the premium need not be taken into account for the purpose of assessing the stamp duty.

I am, Sir,

Your obedient Servant,

15 December 1899.

J. E. FAULKS. 